\title{
LEADING BY SERVING: MEMIMPIN DENGAN MELAYANI ${ }^{1}$
}

Yakob T. Tomatala

\begin{abstract}
ABSTRAK:
Pokok pikiran Leading by Serving atau "Memimpin dengan Melayani," adalah kebenaran tentang kepemimpinan yang bersumber dari Kitab Suci Alkitab. Gagasan "Leading by Serving" ini dibangun berlandaskan ajaran dan praktik kepemimpinan Yesus Kristus. Dalam penelitian, ditemukan bahwa memimpin dengan melayani merupakan pola atau model kepemimpinan yang unik Alkitab, yang menjelaskan bahwa model kepemimpinan pelayan atau servant leadership ini adalah otentik Alkitab dan Kristen, karena diarsiteki oleh Yesus Kristus. Model atau pola kepemimpinan pelayan ini terbukti relevan, pas untuk segala situasi serta semua organisasi, karena sesungguhnya "memimpin sejatinya adalah melayani”. Sebagai upaya mengembangkan gagasan penelitian ini, maka pokok-pokok yang akan dikembangkan adalah antara lain: Pertama, Dasar-dasar Memimpin dengan Melayani; Kedua, Pola Memimpin dengan Melayani; yang diakhiri dengan suatu kesimpulan.
\end{abstract}

Bidang Kajian: Kepemimpinan; Kepemimpinan Kristen; Manajemen dan Administrasi

\section{Pengantar}

Pemimpin akan selalu berada pada tempat teratas, dalam setiap organisasi. Pernyataan tentang Pemimpin sebagai yang akan selalu dan tetap berada di atas atau "the leader will always be at the top" ini menjelaskan bahwa secara prinsip serta kenyataan, tempat Pemimpin akan selalu berada di atas pada puncak kerucut kepemimpinan dari suatu dan setiap oraganisasi. Tempat Pemimpin yang selalu di atas sebagai "the top leader" atau "the top executive leader" ini mengandung implikasi, bahwa kapan pun dan di mana pun suatu organisasi itu ada, Pemimpin akan selalu berada di atas pada puncak kerucut setiap organisasi. Kebenaran ini juga

\footnotetext{
${ }^{1}$ Artikel ini ditulis oleh Dr. Yakob Tomatala (Pendiri dan Ketua STT Jaffray Jakarta 1984-2001; 2011-2017). Dr. Yakob Tomatala adalah lulusan S-3 Kepemimpinan, dari Fuller Theolgical Seminary, Pasadena, California USA, untuk Artikel Jurnal STT Wesley, Jakarta - "Voice of Wesley."
} 
menjelaskan bahwa tempat Pemimpin yang di atas kerucut organisasi ini menunjuk tentang "adanya kuasa kepemimpinan lengkap" atau "complete leadership power ${ }^{2 "}$ padanya sebagai seorang Pemimpin. Kuasa kepemimpinan yang melihatkan "kuasa keahlian (expert power); kuasa penghargaan sosial (refferent power); kuasa mengimbali (reward power); kuasa bertindak tegas (coersive power); kuasa resmi (legitimate atau formal power) dan kuasa rohani (spiritual atau wisdom power)"3 ini merupakan pengabsahan dan keabsahan status dan perannya sebagai Pemimpin. Pengabsahan kuasa kepemimpinan ini ditandai dengan adanya "tugas" (task), yang sama dengan "kewenangan" (authority), yang sama dengan "hak" (privilege), yang sama dengan "kewajiban" (obligation), yang sama dengan tanggung jawab (responsibility), yang sama dengan "pertangungjawaban" (accountability), yang melengkapi Pemimpin dengan "kapasitas lengkap" (complete capacity) untuk memimpin organisasi yang dipercayakan kepadanya. Keabsahan kuasa kepemimpinan Pemimpin ini terbukti dalam upaya memimpin (leading attempt) yang menjelaskan sejauh mana Pemimpin menyelenggarakan kuasa kepemimpinan yang ada padanya (excercise of leadership power) dengan benar dalam organisasi. ${ }^{4}$ Kebenaran tentang kuasa kepemimpinan ini ada pada semua bentuk organisasi, baik organisasi keagamaan mau pun organisasi umum, di mana semua Pemimpin yang memimpin pasti memiliki kuasa organisasi. Kuasa kepemimpinan ini memberikan "otoritas memimpin bagi Pemimpin" namun Pemimpin harus menyikapi dan menerapkannya dengan hikmat (wisdom) sehingga ia dapat bergerak atau memanajemeni "perilaku" (behaviour) dan "gaya" (style) dari atas ke bawah (top down) dan dari bawah ke atas (bottom up) dan "dari dalam di dalam" (inside in) mengelola orang-orang dan sumber-sumber kepemimpinan dalam

\footnotetext{
${ }^{2}$ Leadership Power menjelaskan tentang "kemampuan seutuhnya yang olehnya Pemimpin dapat menyebabkan sesuatu terjadi." Lihat penjelasan "Kuasa Kepemimpinan" dalam buku "Kepemimpinan yang Dinamis" karya Dr. Yakob Tomatala

${ }^{3}$ Ibid

${ }^{4}$ Penyelenggaraan kepemimpinan ini akan memperlihatkan aspek kualitas (unsur benar atau effectivity yaitu doing the right thing); aspek kuantitas (unsur baik atau efficiency yaitu doing the right thing rightly); dan hubungan sehat (unsur hubungan sehat atau healthy organizational relationship) yang produktif (productivity).
} 
setiap upaya memimpin. ${ }^{5}$ Gaya manajemen yang "bottom up" yang disebut di depan ini sering dianggap sebagai cara memimpin dengan melayani, namun dapatlah ditegaskan bahwa hal ini tidak melibatkan "memimpin dengan melayani" dalam arti yang sesungguhnya. Alasan terpenting bagi prinsip ini adalah bahwa memimpin sejatinya dimanajemeni "dari atas ke bawah" (top down) dengan menerapkan otoritas atau kuasa kepemimpinan; memimpin dari "bawah ke atas" (bottom up) dengan bersikap bijak serta arif; dan dari dalam di dalam (inside in) dengan memberdayakan setiap pemimpin pada aras manajerial dan administratif mengedepankan dinamika yang responsif lintas sektor yang menyentuh dan menggerakkan operating core secara dinamis.

Melihat kebenaran tentang tempat dan peran Pemimpin yang begini kuat dalam kepemimpinan, maka kini timbul pertanyaan, apakah pemimpin yang tempatnya selalu di atas kerucut kepemimpinan organisasi dapat memimpin dengan melayani? Pertanyaan susulan yang patut ditanyakan ialah, bagaimana seorang Pemimpin Kristen yang tempatnya juga di atas ini dapat memimpin dengan melayani dalam arti yang sebenarnya? Tatkala Yesus Kristus bersabda, "Anak manusia juga datang bukan untuk dilayani, tetapi untuk melayani dan memberikan nyawanya bagi banyak orang" (Matius 20:28; Markus 10:45), maka Ia sedang menegaskan bahwa memimimpin dengan melayani adalah suatu niscaya, dan dapat dibuktikan, karena "Ia sendiri telah mengajarkan serta mempraktekkannya secara konsisten." Sebagai upaya menjawab pertanyaan-pertanyaan di depan ini, maka hal yang akan dibincangkan adalah antara lain: Pertama, Dasar-dasar Memimpin dengan Melayani; Kedua, Pola Memimpin dengan Melayani Cara Alkitab; yang akan diakhiri dengan suatu kesimpulan.

\footnotetext{
5 Tugas utama Pemimpin adalah "berpikir" (thinking) dalam dan guna mengelola (memanajemeni) orang serta sumber-sumber (resources) kepemimpinan

${ }^{6}$ Eka Darmaputra dengan tegas mengatakan dalam bukunya, Pemimpin yang Memimpin, bahwa "Dari sudut pandang Alkitab, melayani atau memimpin itu memang tidak pernah teori semata melainkan "aksi". "Tindakan". Lebih tepat bila disebut praksis. Apakah praksis itu? Praksis adalah teori yang dijabarkan melalui praktik. Karenanya, praksis adalah praktik. Tetapi praktik yang secara sadar merefleksikan "keyakinan", "prinsip", atau "teori tertentu."
} 


\section{DASAR-DASAR MEMIMPIN DENGAN MELAYANI}

Memimpin dengan melayani atau "leading by serving" adalah suatu model atau pola kepemimpinan yang khas, yang berhubungan dengan "servant leadership" (kepemimpinan hamba). Servant Leadership ini bersumber dari Alkitab, yang secara khusus dipraktikkan oleh Yesus Kristus. ${ }^{7}$ Kebenaran ini menegaskan bahwa "servant leadership" adalah model kepemimpinan Alkitabiah, model kepemimpinan Yesus Krisstus, yang merupakan dasar yang di atasnya ada dinamika untuk memimpin dengan melayani. Kebenaran ini ditegaskan oleh Kenneth Blanchard dengan mengatakan, "I realized that Christian have more in Jesus than just a great spiritual leader; we have a practical and effective leadership model for all organization, for all people, for all situations." ${ }^{8}$ Kebenaran ini menegaskan bahwa model kepemimpinan Yesus Kristus yang dibangun di atas kehiduan, ajaran dan karyanya adalah suatu model kepemimpinan yang luar biasa, karena terfokus kepada "melayani” sebagai kekuatan utama untuk memimpin. Menyusul penegasannya tentang kelebihan model kepemimpinan Yesus ini, Blanchard senjutnya mengatakan "Jesus sent a clear message to all those who would follow Him that leadership was to be first and foremost an act of service."9 Tegas di sini bahwa "kepemimpinan sejatinya menurut pandangan Yesus Kristus adalah melayani," sehingga ini merupakan "inti dari kepemimpinan" yang memimpin dengan melayani. Dalam upaya mengembangkan gagasan ini, maka tugas pertama yang harus dilakukan adalah memaknai servant leadership, sebagai upaya untuk memaknakan serta membangun gagasan tentang apa sesungguhnya "servant leadership" yang memimpin dengan melayani itu. Apa sesungguhnya servant leaderhsip itu, dan apa pola atau modelnya dan bagaimana melaksanakannya dalam upaya memimpin yang dilakukan dengan melayani?

\footnotetext{
${ }^{7}$ Istilah leading by serving ini telah diadopsi oleh berbagai kalangan dewasa ini, tetapi kebenaran tentang memimpin dengan melayani ini "bersumber dari kehidupan, ajaran dan praktek hidup Yesus Kristus" (Markus 10:45; Matius 20:28; Banding Yohanes 13:1-17, 31-35)

${ }^{8}$ Ken Blanchard and Phil Hodges. The Servant Leader.Makati City: Church strenghtening Ministry, Inc. Tahun 2003, Halaman 8-9.

${ }^{9}$ Ibid., halaman 11
} 
Memberikan penjelasan tentang model kepemimpinan Alkitab yang merupakan Model Kepemimpinan Yesus Kristus, Paul Cedar di dalam bukunya "The Strength in Servant Leadership", ${ }^{10}$ ia mengutip Robert Greenleaf yang mengatakan, "The great leader is seen as servant first, and that simple fact is the key to his greatness." Kebenaran ini menunjuk bahwa "Servant Leadership" adalah model kepemimpinan Yesus Kristus, yang menegaskan bahwa “.... Anak manusia datang untuk melayani bukan untuk dilayani” (Matius 20:28; Markus 10:45). Dari sini dapatlah dirumuskan makna dari "servant leadership" atau "kepemimpinan hamba" sebagai kepemimpinan yang melayani. Dalam menguraikan tentang servant leadership Paul Cedar selanjutnya mengatakan, "Servant leadership begins with the heart - with our attitude, with our motives."11 Penegasan Cedar ini menunjuk kepada keunikan servant leadership yang di mulai dari hati. Dalam upaya memperjelas prinsip ini, maka dapat dikatakan bahwa berdasarkan Injil Matius 20:20-28 dan Injil Markus 10:35-45, kebenaran ajaran Yesus Kristus mengenai "servant leadership," menyentuh aspek berikut antara lain yaitu:

Pertama, Servant Leadership diawali dari panggilan TUHAN (ayat 40). Panggilan ini adalah "dasar yang kuat bagi VISI dan MISI kepemimpinan” yang akan diembannya. Panggilan ini juga memberi "otoritas" khusus bagi kepemimpinan sang Pemimpin, sehingga ia menemukan dirinya sebagai Pemimpin kompeten yang andal memimpin.

Kedua, Servant Leadership diisi dengan keandalan "membina hubungan," yang olehnya Pemimpin mampu dan andal membangun, membina serta menjaga hubunganhubungan kepemimpinan menjadi kondusif, sebagai landasan bagi upaya memimpin yang berhasil. Dampak dari keandalan membina hubungan ini adalah Pemimpin akan senantiasa mampu untuk berdiri di atas hubungan-hubungan dengan menghargai pribadi, potensi, cara kerja dan kontribusi dengan selalu memberi apresiasi. Membina dan memelihara hubungan ini

\footnotetext{
${ }^{10}$ Paul Cedar. The Strength in Servant Leadership. Waco, Texas: Word Books. Halaman 23.

${ }^{11}$ Ibid., Halaman 29.
} 
memberi kemampuan bagi Pemimpin untuk "mencipta krisis menjadi peluang" menopang upaya memimpin (leading attempt) yang berkualitas dan dinamis (ayat 35-41);

Ketiga, Servant Leadership dibangun di atas "komitmen untuk mengabdi” dengan mengembangkan "sikap" sebagai "pelayan dan hamba" (ayat 44). Komitmen membangun sikap seperti ini akan meneguhkan pemimpin dengan etika-moral dan etos yang kuat untuk mempertahankan integritas sebagai Pemimpin Rohani, dengan indikator: rendah hati, lembut hati, sabar hati, murah hati, benar hati, baik hati, suci hati, serta siap mengabdi dengan penuh sadar diri untuk berkorban (Matius 5-7); Keempat, Servant Leadership terfokus pada "melayani dengan dedikasi tinggi untuk berkorban" (ayat 45). Dedikasi tinggi lahir dari komitmen yang kuat bagi "disiplin, kualitas dan kerja," ditopang oleh sikap mengabdi yang kokoh. Prinsip dasar "Servant Leadership" yang dikembangkan dari ajaran TUHAN Yesus ini memperlihatkan adanya pola kepemimpinan yang unggul, sebagai dasar pilihan terbaik.

Mengembangkan pokok ini, jika dikatakan secara umum bahwa kepemimpinan adalah proses, kepemimpinan adalah pengaruh, kepemimpinan adalah hubungan, kepemimpinan adalah mengelola orang dan sumber-sumber serta kerja, dan kepemimpinan adalah hasil, maka "Servant Leadership" adalah kepemimpinan yang melayani, atau "kepemimpinan melayani," di mana "Pemimpin memimpin dengan melayani." Pemimpin yang memimpin dengan melayani, akan termotivasi dengan melayani sebagai bagian kehidupannya, gaya hidupnya dan perilaku serta unjuk kerjanya. Pola ini memperlihatkan hadirnya kecenderungan kuat kelebihan dari model atau pola kepemimpinan hamba. Dari pemikiran di depan, dapatlah dikatakan bahwa "Servant Leadership adalah proses mempengaruhi yang diwujudkan melalui upaya mengelola sikap dan gaya serta orang dan sumber-sumber dalam konteks pelayanan guna mendorong kerja sinergis dengan melayani sehingga mendatangkan produktivitas yang membawa manfaat bagi orang banyak, organisasi dan lingkungan," di mana kepemimpinan dijalankan. Di sini, Servant Leadership mengharuskan adanya "pengaruh yang muncul dari hati 
Pemimpin," yang olehnya Pemimpin dapat memimpin dengan melayani. Karena itu, indikator Pemimpin Pelayan (Servant Leader) yang dapat memimpin dengan "melayani dari hati yang bersih,” dilukiskan oleh Paul Cedar dengan membuat paraprasa I Korintus 13:4-5, yang menegaskan, "Pemimpin Hamba itu sabar dan murah hati; Pemimpin Hamba tidak cemburu; Pemimpin Hamba tidak memegahkan diri dan tidak sombong; Pemimpin Hamba tidak melakukan yang tidak sopan dan tidak mencari keuntungan diri sendiri; Pemimpin Hamba tidak pemarah dan tidak menyimpan kesalahan orang lain." Kebenaran tentang Pemimpin Hamba seperti ini memberikan penegasan bahwa ada padanya kekuatan dan standar etika moral dan etos tinggi, yang olehnya ia memiliki integritas kepemimpinan yang teguh yang menguasai hati nuraninya. Pemimpin Hamba seperti ini menunjukkan bahwa ia memiliki integritas yang kuat, di mana integritas kuat inilah yang melindungi diri dan kepemimpinannya ke akhir dengan selamat. Fakta ini terlihat tatkala Jitro memberikan nasihat kepada Musa tentang kepemimpinan (Keluaran 18:21). Di sini ia menasihatkan bahwa Musa harus memilih orang yang memiliki integritas (berhati hamba), sehingga dapat dikatakan bahwa: "Pemimpin Hamba itu cakap (Integritas Intelektual); Pemimpin Hamba itu takut akan Allah (Integritas Rohani); Pemimpin Hamba itu orang yang dapat dipercaya (Integritas Sosial); Pemimpin Hamba itu orang yang benci pengejaran suap (Integritas Ekonomi); dan Pemimpin Hamba itu orang yang rendah hati dan tahu memimpin (Integritas Kerja). Pada sisi lain, Musa sebagai Pemimpin Israel disebut sebagai "Pemimpin yang berhati sangat lembut" (Bilangan 12:3), sebagai indikator bahwa ia adalah "Pemimpin Besar."

Berdasarkan uraian di atas, sangat terlihat, bahwa Pemimpin Hamba adalah "dia yang terpanggil oleh TUHAN menjadi Pemimpin”, di mana ia harus memimpin dengan melayani dan mengendalikan hubungan-hubungan sehat serta mampu mengubah krisis serta konflik menjadi peluang. Pemimpin Hamba bertanggung jawab membangun hubungan-hubungan, di mana ia harus membuktikan bahwa ia memiliki integritas dengan menghadirkan hubungan 
sehat yang kondusif bagi kesehatan organisasi. Pemimpin Hamba seperti inilah yang dapat membuktikan bahwa ia memimpin dengan melayani dari hati, mengargai hubungan guna mencipta sinergi serta gerak kerja yang simultan dan lintas sektor dengan ferforma tinggi. Pemimpin Hamba yang memimpin dari hati dengan melayani menyadari bahwa ia harus meneguhkan komitmen atau janji hatinya kepada diri sendiri, bahwa ia akan mempertahankan sikap sebagai seorang "hamba yang melayani dengan menghambakan dirinya," sehingga ia dapat membuktikan kepempimpinan yang melayani secara otentik. Ken Blanchard dan Phil Hodges dalam mencermati kepemimpinan gereja yang seharusnya berpola kepemimpinan hamba, mereka menyetir, "Dalam hubungan personal, harapan kepemimpinan yang saling menghargai, memperhatikan, berkorban diri, dan terbuka, sering menjadi lemah atau rusak ketika kesombongan atau keangkuhan diri, ketakutan, dan ketidak pedulian menggantikan keakraban dengan isolasi diri. Ini tentu berita yang buruk. Kabar baiknya adalah ada suatu cara yang lebih baik. Ada suatu model peran kepemimpinan yang Anda bisa percayaai, dan nama-Nya adalah Yesus. ${ }^{, 12}$ Di sini dapat dikatakan bahwa dari kondisi organsisasi yang buruk sekalipun, kepemimpinan hamba yang melayani adalah jawaban untuk mengatasi krisis organisasi. Memberikan komentar selanjutnya, Blanchard dan Hodges mengatakan, “Ada satu cara memimpin yang menghormati Allah dan memulihkan kesehatan dan efektivitas kerja serta hubungan baik dalam organisasi. Itulah cara yang Yesus inginkan agar kita ikut sebagai pemimpin: untuk melayani bukan untuk dilayani."13 Yakob Tomatala dalam mengungkapkan kelebihan Kepemimpinan Hamba dari Yesus Kristus menegaskan “core leadeship principles and values-Nya yang agung” dengan mengetakan bahwa kelebihan kepemimpinan Yesus Kristus adalah bahwa: "Ia memimpin dari HATI, berlandaskan KASIH dengan kekuatan KEBENARAN dan KEBAIKKAN" sebagai model kepemimpinan yang par-excellence. ${ }^{14}$

\footnotetext{
${ }^{12}$ Kenneth Blanchard and Phil Hodges. Lead Like Jesus. Jakarta: Visimedia. Tahun 2006, halaman 4.

${ }^{13}$ Ibid.

${ }^{14}$ Yakob Tomatala. Par-Excellence Leadership: Memimpin dari Hati berlandaskan Kasih dengan Kekuatan Kebenaran-Kebaikan. Jakarta: YT Leadership Foundation. Tahun 2011.
} 
Memimpin dari hati model Yesus Kristus menjelaskan bahwa kepemimpinan-Nya dikendalikan oleh nurani (conscientiae), yang didasarkan atas alasan yang benar (the right reason - atau synderesis) yang memberi nilai berkualitas positif dan tinggi kepada sikap kepemimpinan yang mengabdi. Memimpin "dari hati" memudahkan orang untuk berendah hati dan melayani serta menerima orang lain. Memimpin "berlandaskan kasih" menegaskan tentang motif kepemimpinan luhur yang selalu mengupayakan kebaikan tertinggi dengan mengangkat sesama dalam melayani. Memimpin dengan "kekuatan kebenaran" memberikan kekuatan kepada nilai kepemimpinan, yang memimpin melalui melayani yang efektif (doing the right thing - simbol kualitas); dan memimpin dengan "kekuatan kebaikan" melalui melayani yang efisien (doing the right thing rightly - simbol kuantitas). Prinsip kepemimpipinan ini menegaskan bahwa memimpin dengan melayani pola Yesus Kristus adalah suatu keniscayaan yang dapat mewujudkan kepemimpminan berkualitas dan upaya memimpin yang efektif, efisien serta sehat dan produktif pada setiap organisasi. Pola kepemimpinan yang melayani inilah yang menjamin ketegakkan organisasi dan keberhasilan kepemimpinan setiap Pemimpin yang "memimpin dengan melayani dari hati, berlandaskan kasih dengan kekuatan kebenaran-kebaikkan.”

\section{POLA MEMIMPIN DENGAN MELAYANI CARA ALKITAB}

Pola "memimpin dengan melayani” disebut Alkitabiah, karena dibangun di atas ajaran Alkitab. Telah diungkapkan di atas bahwa pola "Kepemimpinan yang Melayani” dibangun di atas prinsip, ajaran dan praktek Yesus Kristus, yaitu: "Melayani dari hati (Matius 9:36-38), berlandaskan kasih (Yohanes 13:1-35; Lukas 10:25-37); dengan kekuatan kebenaran (Yohanes 14;6,27; 8:30-36,46) dan kebaikkan (Matius 11:28-20)." Ini adalah adalah pola inti kepemimpinan Yesus Kristus. Pola ini terfokus kepada melayani sebagai tujuan utama pengabdian-Nya, dengan menyerahkan nyawa-Nya bagi banyak orang (Matius 20:28; Markus 
10:45). Dari sini dapat ditanyakan, "apa kelebihan pola Kepemimpinan Hamba atau Servant Leadership dari Yesus Kristus yang melayani ini dan apa implikasinya bagi kepemimpinan Gereja dan kepemimpinan publik pada masa kini?” Menjawab pertanyan ini, kita dapat memulai dengan menekankan beberapa kebenaran prinsipil yang merupakan kelebihan dari Pola Kepemimpinan Yesus Kristus ini. Prinsip pola kepemimpinan Yesus Kristus ini adalah:

Pertama, Kelebihan Pola Kepemimpinan Hamba yang melayani dapat dirunut sebagai berikut ini: 1) Kepemimpinan Hamba yang melayani meneguhkan komitmen untuk melayani dari hati. Komitmen untuk melayani dari hati ini disertai kesediaan berkorban seperti Yesus (Matius 20:28). Kepemimpinan hamba mengharuskan Pemimpin membangun komitmen “memiliki hati hamba seperti Yesus Kristus.” Memiliki hati hamba bukanlah sesuatu yang dapat direkayasa, karena "hati hamba" adalah "hati Yesus" yang luhur, di mana menghamba dengan kesediaan dan kesigapan melayani (Matius 9:36; 14;14; 15:32) adalah "anugerah Yesus Kristus yang menyelamatkan" (Yohanes 15:16; 10:28-29). Hati hamba adalah hati yang telah dibaharui dari TUHAN (II Korintus 5:17; Roma 12:1-2). Hati hamba, adalah hati yang dikuasai oleh hikmat dari atas (Yakobus 3:13-18), yang menghadirkan keluhuran budi (Yesaya 32:8). Hati hamba adalah hati yang terbangun di dalam kebenaran dan keadilan (Yesaya 32:1-2). Hati hamba adalah hati yang selalu menghadirkan damai sejahtera (Yesaya 32:17; Matius 5:9). Hati hamba adalah hati yang menghamba, yang dibuktikan dengan kesediaan untuk melayani dengan tulus dan berkorban (Matius 20:28,34). Komitmen melayani seperti Yesus ini memberikan kekuatan untuk berkorban dari hati yang mengabdi secara otentik, yang menandakan kualitas sikap mengabdi yang tinggi. 2) Kepemimpinan Hamba yang melayani "meneguhkan motivasi” menjadi kokoh untuk bersikap seperti "pelayan” (diakonos) yang "melayani” (melaksanakan tugas sebagai pelayan) dengan sikap kerelaan mengabdi yang tinggi sebagai seorang "hamba" (doulos) yang penuh pengabdian" dari "status dan peran sebagai hamba" (Matius 20L20-28; Markus 10:35-45). Motivasi melayani seperti ini meneguhkan 
kesediaan berkorban, yang memberikan kekuatan untuk memimpin dengan melayani pola Yesus Kristus. Memimpin dengan melayani seperti ini memungkinkan terciptanya pikiran dan gaya Pemimpin yang proaktif, yang mampu menghadirkan gerakan manajemen "top downbottom up - in side in" yang tulus dan berefektivitas tinggi, yang menyentuh semua lini secara sinergis. 3) Kepemimpinan Hamba yang melayani meneguhkan hubungan-hubungan, dan berimbas positif membangun Tim Kepemimpinan (Leadership Team) yang bersemangat tinggi untuk bersinergi. Kepemimpinan Hamba seperti ini meneguhkan Pemimpin untuk berendah hati dengan "menghargai sesama dari hati, menerima kapasitas setiap orang dengan kelebihan dan kelemahannya; mendukung cara kerja setiap orang dengan tulus, baik dengan sikap dan dukungan sumber lain; dan mengakui kontribusi semua orang dalam kepemimpinannya" dengan selalu memberi apresiasi. Kepemimpinan Hamba yang melayani ini akan mencipta kekuatan Kepemimpinan sebagai Tim, yang akan membuka jalan bagi kinerja bersinergi dengan semangat kerja yang tinggi untuk bergerak secara simultan lintas sektor. 4) Kepemimpinan Hamba meneguhkan upaya memimpin dengan melayani secara otentik, yang ditandai "kesediaan berkorban" demi orang lain dan demi kepemimpinan serta demi kepentingan bersama. Kesediaan berkorban dengan sendirinya akan meneguhkan kepemimpinan yang mengedepankan kehendak baik untuk mengupayakan kebaikkan bagi sesama, sehingga organisasi menjadi kuat. Dengan menguatkan organisasi, maka organissi akan menjadi teguh dan dapat mewadahkan kehidupan, kegiatan dan semangat kerja berkualitas, untuk bekerja bersama secara terpadu meneguhkan kepemimpinan organisasi. 5) Kepemimpinan Hamba meneguhkan untuk “bersikap proaktif responsif” guna melaksanakan upaya memimpin dengan "bekerja sebagai Pemimpin yang melayani." Bekerja sebagai pemimpin yang melayani di sini mengedepankan pelaksanaan kinerja secara berjenjang, menyeluruh dan simultan pada semua lini (Top Town - Bottom Up - Inside In), sehingga "kekuatan melayani" melahirkan "timbal melayani" yang aktif dan dinamis, yang melibatkan 
seluruh komponen SDM organisasi mulai dari level Pemimpin (Top Leader); Manajer (Managerial Level) dan Administratif (Staff and Operating Level - Level Staf dan Pelaksana Ujung Tombak) yang menyentuh pekerjaan operasional di lapangan. Pola Kepemimpinan Hamba yang melayani ini dengan sendirinya memastikan adanya "gerak kehidupan organisasi yang hidup dan dinamis" dengan performa tinggi (high performance) dalam kepemimpinan organisasi, yang nampak pada upaya kerja sinergis simultan yang bersinambung, sehingga terjadi produktivitas yang tinggi.

Kedua, Kelebihan pola memimpin dengan melayani adalah menyiapkan "plat form" bagi terciptanya kepemimpinan yang sehat. Landasan bagi kepemimpinan yang sehat ini dibangun di atas kebenaran "Servant Leadership" yang melibatkan faktor-faktor fundamental berikut: 1) Sikap Pemimpin akan cenderung "berhikmat," karena ia memimpin dari hati yang terjaga baik (Amsal 4:23). Pemimpin yang hatinya terjaga, akan cenderung menjaga serta mengontrol pikiran, sikap, kata, gaya dan perbuatannya, sehingga ia mampu memimpin dengan bijaksana dan memberkati (Amsal 4:25-27). Sikap pemimpin yang seperti ini menampakkan “integritas kuat,” yang menandakan keluhuran budi Pemimpin (Yesya 32:8). Integritas dari keluhuran budi ini adalah "kuasa roh mengabdi" (dedicated spirit power) yang olehnya ia sendiri terlindung dari ancaman "degradasi etika-moral-etos" dirinya, di mana olehnya ada kekuatan yang meneguhkan semangat untuk memimpin dengan melayani secara konsisten dan konstan dalam seluruh proses kepemimpinan. 2) Pemimpin akan memperlihatkan "kualitas kepribadian" yang kuat dan berterima. Kualitas kepemimpinan Pemimpin yang kuat dan berterima ini akan menolong Pemimpin untuk bersikap arif, tidak memilah dan membedakan, dan terhindar dati gaya KKN, primordialistis dan kepentingan sesaat. Pemimpin akan terlihat memiliki etika dan moralitas kerja dengan etos yang tinggi, sehingga ia menjadi "Pemimpin patron dalam kepemimpinan yang sehat" bagi bawahan dan semua komponen SDM dalam kepemimpinannya. Kualitas kepribadian ini juga menampakkan adanya pengaruh positif yang 
nampak dari kehidupan Pemimpin, yang olehnya "kuasa dan kewibawaan serta pengaruh kepemimpinannya" berkembang menopang diri dan upaya memimpinnya yang berhasil. 3) Kekuatan memimpin dengan melayani akan menyediakan ruang gerak bagi pengembangan sikap dan "rasa hormat" kepada diri dan sesama dalam oraganisasi. Kekuatan rasa hormat ini pertama-tama akan meneguhkan "rasa hormat kepada diri" (self esteem) yang berimbas pada lahirnya sikap positif dan percaya diri tinggi, yang berujung kepada rasa homat bagi sesama dan kerja kepemimpinan yang diemban. Sikap rasa hormat seperti ini melibatkan penyentuhan rohani, sosial, ekonomi, kelompok dan pribadi, sehingga melahirkan "semangat kesatuan dan persatuan organisasi” yang semakin teguh, yang menjamin keberhasilan upaya memimpin sang Pemimpin (Kejadian11:6). 4) Kepemimpinan yang sehat akan tercipta dari kepemimpinan yang melayani, di mana Pemimpin yang telah terpanggil akan melihat VISI dan MISI kepemimpinan dengan jelas. Melalui VISI dan MISI inilah ia dapat berbagi dan meneguhkan semua komponen SDM untuk terlibat dalam kepemimpinan secara terencana dan bertujuan (Matius 3:13-17; 28:18-20). Pemimpin yang melayani dari hati seperti ini selalu "tahu siapa dirinya, alasan mengapa ia ada, apa yang harus dikerjakannya, dan bagaimana membawa orang-orangnya ke tempat di mana mereka seharusnya berada, yaitu di suatu masa depan yang jelas dan pasti.” 5) Kepemimpinan yang melayani menjamin keberhasilan upaya kerja, di mana Pemimpin yang telah melihat VISI dan MISI kepemimpinan, Memanajemeni Perancaan Strategis dengan jelas, Memanajemeni Organisasi dengan pendekatan Total Quality Management (TQM), Memanajemeni SDM dan sumber-sumber lain dengan benar dan baik, Memanajemeni Upaya Memimpin dengan Manajemen Performasnsi Tinggi (High Performance Management) andal, Memanajemeni Krisis dan Konflik Internal dan Eksternal dengan hikmat, yang menjamin upaya memimpin yang berkualitas mencapai keberhasilan yang pasti (Lihat: Nehemia 1-6). Hal awal yang akan diterima Pemimpin yang melayani ialah bahwa "ia akan menuai imbasan dukungan dari orang-orang yang dipimpinnya" untuk 
mengabdi bersama dengan semangat kerja yang tinggi berlandaskan komitmen dan dedikasi yang teguh untuk mengabdi dalam kerja (Nehemia 2:20). Selanjutnya Pemimpin yang melayani akan melihat krisis sebagai peluang, dan dapat mencipta peluang baru untuk masuk kepada upaya performa kerja yang berakselarasi tinggi (high accelerated leadeship performance), sehingga mencapai pencapaian kerja lepas pencapaian kerja yang ditandai adanya keberhasilan kepemimpinan (Banding: Yusuf dan Nehemia di dalam Alkitab).

Ketiga, Pola kepemimpinan yang melayani akan melindungi Pemimpin, Orang yang dipimpin; Organisasi dan Lingkungan di mana kepemimpinan dijalankan. Hal-hal fundamental yang akan terbukti adalah antara lain: 1) Pemimpin yang memimpin dengan melayani akan dengan sendirinya menandakan kerendahan hati yang tulus, sebagai bukti keluhuran budinya (Yesaya 32:8; Yakobus 3:13-18). Kerencahan hati seperi ini tidak menjebak Pemimpin ke dalam "inferiority complex" yang menyebabkan orang "berendah hati yang berpura-pura" alias berendah diri. Berendah diri memperlihatkan bahwa orangnya dari luar terlihat rendah hati, tetapi di dalam "berhati tuan besar." Indikator dari sikap ini adalah, ada terselip sikap munafik. Sikap munafik ini diselubungi oleh wajah dan kata-kata yang dimaniskan, dibumbuhi janjijanji (pepesan) yang tidak akan dipenuhi. Pemimpin yang berendah diri dan munafik seperti ini akan terlihat suka memperdayakan orang atas nama pemberdayaan, dengan menggunakan kepemimpinan dan organisasi sebagai tujuan untuk membesarkan diri, demi kepentingan diri sendiri. Lain halnya Pemimpin yang memimpin dengan melayani dari hati yang tulus, ia akan rela berkorban untuk membesarkan organisasi dan orang-orangnya. Ia akan cenderung mendahulukan kepentingan organisasi dan orang-orangnya, yang pada gilirannya ia akan menjadi besar, tetapi tidak membesar-besarkan diri. 2) Orang-orang yang dipimpin dengan sentuhan kerendahan hati Pemimpin yang memimpin dengan melayani, akan merasa diperlakukan secara hormat dan wajar. Mereka akan merasa "harga dirinya di hormati," mereka akan "memperoleh identitias diri" dari organisasi dan menjadikan "Pemimpin sebagai patron" 
dan mereka juga akan menjadikan organisasi di mana mereka ada sebagai milik sendiri, sebagai tanda dukungan kepada Pemimpin. Orang-orang yang dipimpin akan merasa terlindung, di mana harapan mereka yang dipundakkan di bahu Pemimpin, dan masa depannya yang dipetaruhkan kepada Pemimpin, diyakini sepenuh hati bahwa akan terpenuhi. 3) Pemimpin yang memimpin dengan melayani dari hati yang tulus akan tertolong untuk membedakan "mana bawahan yang otentik bawahan, dan mana bawahan yang penjilat" (ingratiator - one who ingratiates). Bawahan penjilat pada umumnya suka menjilat (ingratiation) demi kepentingan dirinya. Bawahan seperti ini biasanya suka menjilat untuk mengambil hati Pemimpin, mereka akan terlihat sebagai orang setia yang sangat mendukung, tetapi akan rapuh jika ada tantangan kepemimpinan yang dihadapi Pemimpin. Penjilat akan menjilat siapa pun yang akan memberi manfaat dan keuntungan bagi dirinya. Kesetiaan penjilat biasanya tertuju pada mencari keuntungan bagi dirinya saja. Pemimpin yang memimpin dengan melayani akan terbukti arif menyikapi para penjilat, karena ia memiliki "mata Yesus Kristus" yang dapat mengidentifikasi Yudas Iskariot di sekitarnya, dan tidak tertipu oleh kegombalan penjilat. 4) Pemimpin yang memimpin dengan melayani akan terbukti "taat dan setia" kepada dirinya, TUHAN-nya, Orang-orangnya, dan Organisasinya. Ia dapat dipercaya sepenuhnya (II Timotius 2:2; Filipi 2:8-11). Kata-kata dan janji-janjinya dapat dipegang. Ia dapat dipercayai, ia dapat diandalkan sebagai Pemimpin yang berintegritas tinggi. Ia dapat diharapkan. 5) Pemimpin yang memimpin dari hati yang melayani mengembangkan "postur kepemimpinan yang menghamba kepada TUHAN, untuk mengabdi dengan penuh dedikasi serta setia” kepada organisasi dan orang-orangnya. Pemimpin seperti ini sadar bahwa karena anugerah TUHAN ia ada, maka ia mengornati dirinya, kepemimpinan dan organisasinya, pekerjaannya, orang-orangnya, yang dilakukannya dengan penuh hormat, sehingga ia dapat bertahan sampai ke akhir dan "finishing 
well," 15 karena tidak terganggu oleh "diskredit diri" (self discredited) karena terhindar dari tindakan amoral tidak terpuji. Ia juga tidak terhalang oleh halangan atau rintangan organisasi atau orang-orang yang menghalangi perkembangan dan karirnya, di mana ia akan terus maju apa pun rintangannya, karena ia mengerti siapa dirinya, apa kepercayaan yang diterimanya dan sepenuhnya bertanggung jawab kepada TUHAN-nya atas panggilan kepemimpinan yang diberikan kepadanya yang dilakukannya dengan setia sampai ke akhir. Pemimpin seperti ini akan meninggalkan "cerita kepemimpinan hebat yang melegenda," dari "kepemimpinan yang finishing well," karena ia memimpin dari hati, berlandaskan kasih dengan kekuatan kebenaran-kebaikkan untuk melayani dengan berkorban seperti Yesus Kristus, TUHAN-nya (Matius 20:28; Markus 10:45). Pemimpin yang memimpin dengan melayani dari hati ini pada akhirnya akan "finishing well" serta meninggalkan "cerita berkat dari kepemimpinannya" yang menggangkat, memberkati dan menegukan kehidupan banyak orang. Orang-orang inilah yang "punya gawe" untuk terus menuturkan "cerita hebat dari kepemipinan hamba yang memimpin dengan melayani," yaitu "Kepemimpinan Yesus Kristus yang Par-excellence."

\section{KESIMPULAN}

Uraian tentang pokok Leading by Serving: Memimpin dengan Melayani” telah diuraikan dengan menegaskan dua hal penting yaitu: Pertama, Dasar-dasar Memimpin dengan Melayani; Kedua, Pola Memimpin dengan Melayani cara Alkitab. Menyimak uraian tentang pokok-pokok ini dapatlah dikatakan bahwa sesungguhnya ada pola atau model kepempinan terbaik yang dapat digunakan oleh gereja dan siapa pun untuk memimpin dan melaksanakan upaya kepempinan secara benar, baik sehat dan produktif, yaitu Kepemmpinan Yesus Kristus, yang intinya "memimpin dengan melayani dari hati, berlandaskan kasih, dengan

\footnotetext{
${ }^{15}$ Konsep "Finishing Well" ini dikembangkan oleh Profesor Dr. J. Robert Clinton, Pakar Kepemimpinan dan Pencipta Leadership Emergence Theory, dari Fuller Theological Seminary, Pasadena, California USA
} 
kekuatan kebenaran - kebaikkan." Sama seperti kehidupan, karya, dan ajaran Yesus Kristus yang kokoh berdiri menjalani sejarah, maka kepemimpinan-Nya juga "tidak lekang karena panas, tidak lapuk karena hujan sejarah dan kultur manusia.” Profesor Sanjaya dalam bukunya Kepemimpinan Kristen mensinyalir, bahwa "Kepempinan Yesus Kristus yang hebat ini sering diaborsi oleh orang Kristen dan Gereja, tetapi diadopsi oleh orang lain." Kepemimpinannya yang beranjak dari "kain dan baskom" sebagai tanda bukti melayani, ternyata begitu hebat dan efektif, efisien serta sehat, sehingga diambil dan dipraktekkan oleh orang lain dan mereka menuai sukses. Hm, sudah saatnya kembali ke sumber, yaitu: "Memimpin seperti Yesus Kristus dari hati, berlandaskan kasih, dengan kekuatan kebenaran-kebaikkan" untuk melayani dan sukses. Selamat memimpin dengan melayani seperti Yesus Kristus. Kiranya!

Jakarta, 1 Maret2019

Dr. Yakob Tomatala, M.Div.,M.I.S.,M.A 


\section{REFERENSI}

Blanchard, Kenneth dan Phil Hodges

2003 The Servant Leader. Makati: Church Strengtehning Ministry Inc.

2006 Lead Like Jesus. Jakarta: Visimedia.

Callahan, Kennon L.

1990 Effective Church Leaderhip. San Francisco: Harper and Row.

Cedar, Paul A.

1997 Strength in Servant Leadership. Waco, Texas: Word Books.

Dale, Robert D.

1992 Pelayan sebagai Pemimpin. Malang: Gandum Mas.

Darmaputra, Eka

2011 Pemimpin yang Memimpin. Yogyakarta: Kairos.

de Jesus, Benjamin P.

1990 Effective Church Leaderhip. San Francisco: Harper and Row.

Greenleaf, Robert K.

1984 Leadeship That is Chrisian. Zamboaga City: Camacop.

Lucado, Max

2010 Just Like Jesus. Batam Centre: Interaksara.

Sanjaya

Kepemimpinan Kristen. Yogyakarta: Kairos.

Tomatala, Yakob

1997 Kepemimpinan yang Dinamis. Jakarta: YT Leadership Foundation.

2002 Kepemimpinan Kristen. Jakarta: YT Leadership Foundation

2011 Par-Excellence Leadership. Jakarta: YT Leadership Foundation.

2015 Servant Leadership: Memimpin sebagai Pelayan dengan Melayani. Artikel pada Buku Apresiasi Emeritasi Pendeta H. Nainggolan, Tahun 2015.

Wilkes, Gene C.

----- Jesus on Leadership. Jakarta: PT Bhuana Ilmu Populer. 